\title{
Sinophobia during the Covid-19 Pandemic: Identity, Belonging, and International Politics
}

\author{
Zhipeng Gao ${ }^{1}$
}

Accepted: 22 September 2021 / Published online: 4 October 2021

(c) The Author(s), under exclusive licence to Springer Science+Business Media, LLC, part of Springer Nature 2021

\begin{abstract}
In many countries, Sinophobia or discrimination against Chinese has taken place amid the Covid-19 pandemic. While this wave of Sinophobia is popularly understood to be based on a stereotypical association of Chinese with coronavirus, I argue that at a time of international tensions surrounding China, political antipathy toward China and Chinese matters as well. Thus, there is a phenomenon of "triple conflation" in which the health, racial, and political/national statuses of Chinese people become intermingled. In this study, I examine this triple conflation based on dozens of select cases covering Sinophobic actions of governments, politicians, media, businesses and lay persons in North America, Australia, New Zealand, and Western Europe. My study consists of three parts using three respective interdisciplinary approaches. First, using a sociological approach, I argue that the racial and national statuses of Chinese are both, and sometimes interchangeably, used as identity markers for implementing containment, a public health measure that easily leads to stigmatization. Second, using a discursive approach, I examine how political claims unfavorable to China/Chinese are constructed in discussions of the pandemic. Third, using an interpretive approach, I analyze how Covid bio-political metaphors present certain imaginaries depicting Chinese as suspicious bio-political subjects. These three parts are unified in my analysis of the geopolitics of belonging, in which Chinese people's rights to certain social and physical spaces are contested sometimes thorough administrative means (such as travel restriction) and sometimes through mental representations (such as the imagination of Chinese as alien).
\end{abstract}

Keywords Covid-19 $\cdot$ Chinese $\cdot$ Health $\cdot$ Identity $\cdot$ Politics $\cdot$ Racism $\cdot$ Belonging

Zhipeng Gao

zgao@aup.edu

1 Department of Psychology, Health and Gender, The American University of Paris, Paris, France 


\section{Introduction: The Phenomenon of Triple Conflation}

Since the outbreak of Covid-19, a new wave of Sinophobia, namely discrimination against Chinese, has emerged internationally (Kong et al., 2021; Borja et al., 2020b; Schild et al., 2020). The "China virus" expression showed up in street graffiti and social media, Chinese restaurants are shunned, and homestay providers stopped hosting Chinese students. Targeted on the basis of their physical appearances and national origin, Chinese individuals have been avoided, yelled at, coughed on, spit on, punched, kicked, and shot. Victims range from toddlers to the elderly. Sadly, even healthcare workers of Chinese descent became the butt of racist abuses while combating Covid-19 (Corley, 2020; Jeung et al., 2020; Tavernise \& Oppel, 2020). As far as Chinese are concerned, social distancing often turned out to be racial distancing.

It has been popularly understood that today's Sinophobia stems from a stereotypical association between Chinese people and coronavirus (Kim \& Shah, 2020). Chinese have been frequently called to be "dirty", "disease-ridden", and bat-eating ( $\mathrm{Li}$, 2020; Schild et al., 2020; Jeung et al., 2020). These claims tap into a century-old stereotyping practice that associates particular racialized groups with disease (Trumper \& Phillips, 1997; Kim \& Shah, 2020; Viladrich, 2021). In one of the most wellknown events, one thousand Jews were burned alive for having allegedly spread pestilence by poisoning the wells (Snowden, 2019). Although there exist nomenclatures stigmatizing white nations-such as "French disease", "German measles" and "English sweating sickness", disease-related racism today more often target particular vulnerable racialized groups, such as Chinese (White, 2020). Let us call this conflation of race and health status "double conflation", to be contrasted with the "triple conflation" to be introduced below.

A less visible condition for Sinophobia is the international political tensions surrounding China (Patey, 2021). The 2003 SARS can serve as a helpful point of reference to bring the significance of geopolitics into perspective. Both SRAS and Covid-19 spread from China to other countries and led to discrimination against overseas Chinese (Keil \& Ali, 2006; Leung, 2008). What differentiates the present from 2003 is international tensions surrounding China, including the trade war as well as debates regarding China's authoritarianism and human rights condition. Let me offer a few snapshots of the political matter: A Wall Street Journal article's dubbing of the pandemic having been caused by a "communist coronavirus" (Henninger, 2020), an Instagram joke that "coronavirus won't last for long because it is made in China" (Beech, 2020), and a university student leader's comment that Chinese deserve the virus due to the confinement of Muslims in China. These commentaries tap into a range of political issues including communism, international trade, and human rights. In light of these observations, I argue that Chinese are sometimes discriminated against not only because of their racial identities, but also because of their perceived Chinese citizenship or at least some forms of national/political connections with China. A few scholars have pointed out the role of geopolitics in Sinophobia (Li \& Nicholson Jr, 2021; Gao, 2021b; Dionne \& Turkmen, 2020; Reny $\&$ Barreto, 2020, 19; Borja et al., 2020a), but the exact mechanisms underlying this 
process remain unclear. This study thus seeks to investigate how international politics contribute to Sinophobia.

In order to account for the political dimension, I argue that we need to expand our analytic framework. I propose that on top of the prevalent "double conflation", we are sometimes witnessing a "triple conflation", namely the conflation of not only the racial and health statuses but also the political/national identities of Chinese. When making this proposal, I expect one major objection. Skeptical readers might suggest that the political matter could be independent of Covid-related Sinophobia. In other words, political hostility towards China and Chinese merely takes place simultaneously alongside Covid-related Sinophobia, and this overlap does not equal to conflation. In response to this objection, the main task of this study is to demonstrate that there is indeed a conflation. I will elaborate on how politically-motivated Sinophobia becomes interwoven with racial and health concerns to form a tightly knit triple conflation.

I develop the framework of triple conflation from three angles: the politics of spatial belonging, the construction of political discourse, and the use of bio-political metaphors. First, concerning the politics of spatial belonging (Yuval-Davis, 2006; Antonsich, 2010), I make a sociologically based analysis of how the racial and polit$\mathrm{ical} /$ national statuses of Chinese are both used, sometimes interchangeably, as identity markers to identify Chinese individuals as potential carriers of coronavirus. Second, concerning the construction of political discourse, I take a discursive approach to examine how politicians, media, enterprise owners and lay persons make claims that interweave political issues into their discussions of China/Chinese at a time of Covid. Third, concerning bio-political metaphors, I take an interpretive approach to analyze, in light of theories of illness metaphor (Martin, 1990; Musolff, 2010; Sontag, 2001), how Covid metaphors symbolically and affectively merge racial, political and health issues. Together, I use these three approaches to examine the geopolitics of belonging, namely how Chinese are denied rights to certain social and physical spaces. The geopolitics of belonging manifests sometimes administratively, such as through travel restriction, and sometimes mentally, such as through popular imagination of Chinese individuals as suspicious bio-political subjects.

\section{Methods and Data}

The phenomenon of triple conflation cannot be explained within any single disciplinary framework. Thus, I applied theories and methods from a few disciplines including psychology, sociology, political science and cultural studies (Teo, 2017). More specifically, I applied sociological, discursive, and interpretive approaches.

First, my sociological approach was defined by contextualization. Many social scientists prefer to work with a tight cluster of data to represent a highly specified group, often at the expense of contextual information. Ethnographically informed sociologists value an alternative form of analytic rigor by prioritizing contextualization (Marcus, 1995). Given that the formation of Sinophobia involves various social actors and institutions, such as governments, politicians, media, businesses, and lay 
persons, I scouted a broad range of data to establish a holistic picture of multiple interconnected contexts in which Sinophobia propagates.

Second, I applied discourse analysis to analyze how political claims are incorporated into discussions of race and health. In particular, I chose critical discourse analysis because it enabled me to identify what mental representations of Chinese arise from what institutional and ideological contexts, such as international trade and antipathy towards communism (Fairclough \& Wodak, 1997; Van Dijk, 2001; Bischoping \& Gazso, 2016). I pay particular attention to discourses originating from three sources: politicians, the mass media, and lay persons.

Third, influenced by cultural studies, I adopted a hermeneutic interpretive approach (Denzin, 1997; Saukko, 2003; Willig, 2017). Many social scientists aim to produce positivist representation of objective and observable properties of reality. This part of my study, in contrast, is interested in exploring how social actors symbolically and imaginatively make sense of reality. Specifically, I analyzed how Covid-based metaphors offer particular imaginaries of China/Chinese that bring political, racial and health issues together in contagious ways (E. Martin, 1990; Musolff, 2010; Sontag, 2001).

My data collection consisted of two stages. In the first stage, in 2020 and 2021, I broadly collected information available online in both English and Chinese. I gathered over 2000 Sinophobic incidents that took place in North America, Australia, New Zealand, and Western Europe. My data came from three sources. First, I reviewed major databases and findings compiled by scholars, government agencies and NGOs (Kong et al., 2021; Manojlovic, 2021; Schild et al., 2020; Jeung et al., 2020). Second, I followed on a daily basis dozens of major news media as well as social media concerning overseas Chinese, including Twitter, Facebook, as well as Chinese social media platforms WeChat and Douban. Third, I searched online news coverages and social media posts using a group of key words including but not limited to "China", "Chinese immigrants", "racism", "Sinophobia", "Covid-19", "coronavirus", "trade war" and "public health".

It is important to note that I did not attempt to structuralize my source of data following a mechanistic procedure. Such a positivist data-driven approach would constrain my capacity of conceptual exploration as required by the novel phenomenon of tripe conflation. My liberal data collection strategy was instead meant to achieve ethnographic representation, or the inclusion of various social actors and contexts. In this regard, it was more important to cover the whole range of political spectrum from, say, the left-wing CNN and the Guardian to the ultra-right Fox News, than to exhaust all publications by one particular news outlet.

In the second stage, I performed purposeful sampling to select a few dozen "telling" cases out of the 2000 plus Sinophobic incidents (Campbell et al., 2020; Patton, 2007). I considered a case telling when it reveals the social, symbolic, and psychological processes underlying Sinophobia. For example, someone calling a Chinese individual "dirty" is more telling than a physical assault. The racist slur is more informative of the particular mental representation of Chinese, even though it arguably inflicts less harm. This purposeful use of case studies is consistent with interpretive analysis in cultural studies. From the perspective of qualitative research, the content of cases is more important than the quantity (Boddy, 2016). In so far as my 
study aims to conceptualize the phenomenon of triple conflation, it is more important to extract information that illuminates the unique characteristics of Sinophobia than to, say, exhaustively cover all racist incidents using statistical methods.

Lastly, I should clarify that my study deliberately covers "Chinese" of different kinds. The individuals I focus on could be ethnic or national Chinese; they could be citizens, permanent residents, international students or travellers in the host societies; they could be first-generation immigrants or locally born. Against the common strategy of highly specified sampling, this is an innovative decision made to address a novel phenomenon which precisely involves the confusion of various kinds of "Chinese". For example, when racists shout slurs to a Chinese person walking in the street, they usually do so on the basis of casual racial profiling without attempting to verify the victim's citizenship status. Thus, the common sampling strategy of focusing on one well defined group would precisely evade the phenomenon of triple conflation.

\section{The Politics of Spatial Belonging}

To begin with, I argue that discrimination against Chinese partially stemmed from a politics of spatial belonging (Yuval-Davis, 2006; Antonsich, 2010). Until mass vaccination, the primary response to Covid-19 lies in containment. Comprised of quarantine, isolation and social distancing, containment is a spatially-based approach to managing bodies suspected to be potential carriers of coronavirus. As a century-old public health approach to infectious disease, containment has proven to be effective but also risks heavy cost of human rights (Gostin et al., 2003; R. Martin, 2006; Wilder-Smith \& Freedman, 2020). In this section, I examine how various actors including governments, border control, business owners and lay persons carry out containment measures at various locales such as airports, supermarkets, gas stations, classrooms, playgrounds, and restaurants. I suggest that the politics of spatial belonging amid a public health crisis explains why the current Sinophobia frequently involves physical exclusion (Fottrell, 2020). For example, in the U.S. and Canada, disproportionally high rates $-18 \%$ and $10 \%$ respectively - of all reported Sinophobic incidents involved some forms of shunning or exclusion (Kong et al., 2021; Jeung et al., 2021).

While Chinese were popularly perceived to potentially pose a higher public health risk, it is unclear who constitutes Chinese. When various agents enact containment measures targeting Chinese, they often confusedly apply multiple criteria to determine who are Chinese. Sometimes one is considered Chinese based on his/her citizenship status as evidenced by legal documents, and other times one is deemed Chinese based on his/her physical appearance. Thus, both racial and citizenship statuses were used, sometimes exchangeably, to indicate potential public health risk. This is a key mechanism through which national and racial statuses become conflated. In the following, I discuss such conflation in two contexts: The first context involves institutionalized exclusion of Chinese in aggregates, and the second involves grassroots exclusion of Chinese individuals.

First, let us look at international travel restriction created by various governments. This constitutes institutionalized containment measures against Chinese 
at the aggregate level. As of April 2020, 96 countries and territories had imposed travel restrictions against China (Kiernan, 2020). While visa offices and border control barred travellers on the basis of their Chinese citizenship statuses, some airlines make decisions based on China-related travel histories. The lack of consistency often led to problematic treatment of travellers with a Chinese background of any kinds. For example, a Norwegian cruise ship barred a passenger because she held a Chinese passport, even though she had been a Canadian permanent resident for 15 years and had not visited China since the coronavirus outbreak (Molina \& Kupfer, 2020). When different agents apply different criteria to screen out "Chinese", they create a conflation of national and racial statuses. In whichever case, suspicion of the health status of Chinese leads to the denial of their rights to certain spaces.

Second, let us examine Sinophobia within national territories. Here, lay persons and small business owners have initiated micro containment measures targeting Chinese individuals. For example, in early 2020, restaurants in multiple countries posted signs to refuse Chinese costumers (Fottrell, 2020). To some researchers, these everyday discriminations might appear to be partially motivated by a behavioral tendency called disease avoidance - the practice of avoiding individuals suspected to have infectious disease (Oaten et al., 2011). Disease avoidance might have a functional basis but can easily breed stigmatization. Usually, disease avoidance is triggered by visible signs of infectious disease (Oaten et al., 2011). This could explain why Asians coughing caused particular concerns (Wang et al., 2021). Although, it should be noted that in most cases, Chinese individuals are shunned without displaying any signs of virus infection. Instead, they are targeted on the basis of a vague suspicion against "Chinese" in general, a stereotype that involves a slippage between racial and national memberships.

The slippage between racial and national statuses stems from the fact that everyday Sinophobic encounters rarely involve formal verification of a Chinese-looking person's actual citizenship status. Instead, the target is chosen through casual visual racial profiling, the assessment of one's racial identity based on physical appearance. Visual racial profiling is a major mechanism to cause the conflation of racial and national statuses. In numerous cases, ethnic Chinese who are local citizens are shunned, even though they may have never travelled to China. Meanwhile, the conflation has led to an expansion of Sinophobia to discrimination against East Asians in general because of the latter's physical resemblance, and possibly social-physical proximity, to Chinese (Kong et al., 2021; Li \& Nicholson Jr, 2021; Tavernise \& Oppel, 2020). For example, in London, a group of youth attacked a Singaporean student while shouting "we don't want your coronavirus in our country", apparently mistaking him for a Chinese national (BBC News, 2021). Italy's Santa Cecilia Conservatory banned all East Asian students from taking classes, irrespective of whether these students had recently travelled to the infected regions (Stefano \& Noack, 2020).

Now, I have argued that whether across the China-West borders or inside a particular Western country, attempts to contain the movement of Chinese people frequently conflate their racial and national statuses, both taken as signs of potential health risks. The politics of spatial belonging amid a global public health crisis can clearly distinguish the current Sinophobia from other types of racism, such as 
anti-Black racism citing their lower professional achievements and Islamophobia citing terrorism.

The last question: how should we evaluate the politics of spatial belonging as manifest in the containment of Chinese? One might argue that from a public health perspective, the barring of Chinese travellers is not completely without justification. Especially in early 2020, when China was known to be the only epicentre, other governments might feel obliged to protect their populations from the spreading coronavirus, and travel ban appeared to be an immediately available option. At that time, such decision was not driven by antipathy towards China/Chinese as much as by fear of coronavirus. Nor was the panicky reaction targeted at China/Chinese only. The Canadian government, for example, soon listed Iran to be the second restricted source of travellers, next to China's Hubei province (and not China as a whole). Later on, when China put its own epidemic under control, it similarly closed its border to foreigners and even its own citizens (Gao, 2021a; Xu et al., 2021). In short, in early 2020, the institutionalized containment measures were mostly driven by a public health concern. When Chinese individuals' racial and national statuses were concerned, they often served as expedient_albeit problematic-identity markers for other countries to keep coronavirus at bay.

However, later, when Covid-19 evolved into a pandemic, it could no longer be said that the Chinese population poses any greater health risk than other populations do. Neither racial nor national statuses of Chinese could serve as an effective identity marker for containment efforts. In fact, after the initial outbreak, China has been able to control its level of virus infection to a very low level. Meanwhile, in Canada and Italy, several communities with high concentrations of Chinese immigrants displayed significantly lower infection rates than the local averages, thanks to their extra precaution learned from China (Krause \& Bressan, 2020; Yeung, 2020). Yet, Sinophobia continued to climb. Now, this puzzle requires us to move beyond the public health perspective.

\section{The Construction of Political Discourse}

In the previous section, I have made sociological analysis of the politics of spatial belonging as manifest in the exclusion of Chinese using their racial and national statuses as identity markers. In this section, I shift to a discursive approach with a focus on how Covid-based Sinophobic claims are constructed in reference to international political tensions surrounding China. A few sarcastic visual arts illustrate such politicized claims: a drawing of coronavirus as the crown of China's President, a cartoon of the Chinese flag with its stars substituted by coronavirus, and a photo of a person in protective gears subtitled "made in China". In the following, though, I will focus on text-based discourses because they permit in-depth analysis of the underlying reasoning processes.

The construction of Sinophobic discourses begins with the naming of coronavirus. Amid the US-China trade war, the U.S. President Donald Trump and his Republican associates insisted on using the "China virus" label instead of neutral terms recommended by the WHO (Li \& Nicholson Jr, 2021; Borja et al., 2020a). The 
exchangeable use of "China virus" and "foreign virus" assimilates the existing xenophobia in the U.S. to pinpoint China to be the major political opponent of the country while attenuating the administration's responsibility in its flawed response to the pandemic. Meanwhile, the problematic naming practice has been fueled by controversies regarding the origin of coronavirus (Borja et al., 2020a; Gao, 2021c; Tavernise \& Oppel, 2020). After Chinese diplomats suggested that Covid-19 originated in the U.S. and not in China (Zhao, 2021), a CNN reporter pushed back, suggesting that the "Wuhan virus" label should be used, "to make sure that folks know where the epicenter of this virus really is" (Christy, 2020).

The origin controversy further tapped into Western mass mistrust in the Chinese government's administrative capacity. When Fox News host Jesse Watters asserted that coronavirus originated in China, he explained: "Because they (Chinese) have these markets where they are eating raw bats and snakes. They are a very hungry people. The Chinese communist government cannot feed the people, and they are desperate. This food is uncooked; it's unsafe" (Choi, 2020). While depicting Chinese to act out of animal instinct for survival and lack the capacity for human dignity, Watters attributes this backward state to the Chinese government. In his narrative, the problems of wild-animal eating due to poverty is but a lynchpin that connects China's governance to the emergence of coronavirus, completing a chain of events that conflates illness, race, and national governance.

Notably, the Fox News host calls the Chinese government "communist", a label that has much potency to trigger the lingering Cold War hostility but pays little heed to the fact that China has for decades drastically shifted away from communism. The Fox News host is not alone in using the discourse of communism. A Wall Street Journal article similarly dubbed coronavirus as a "communist coronavirus" (Henninger, 2020). Starting with a discussion of the Chinese government's responsibility for the Covid crisis, this article expands to a wide range of governance problems including air pollution, mass surveillance, and Hong Kong democracy. In this discursive construction, the Covid crisis serves as a springboard for the author to enter elaborate political accusations.

The unfavorable attitude of the U.S. toward China is shared by Canada, which has been recently involved in the extradition of Meng Wanzhou, an executive of China's telecommunication Giant Huawei, and has had two citizens detained by China in what appears to be an act of retaliation (Bogerd \& Creemers, 2020). Against the backdrop of the historical low bilateral relation, a major Canadian news media claimed that during the first weeks of coronavirus outbreak in China, overseas Chinese purchased and mailed face masks to China not because they were worried about their families there, but because they were abetted by the Chinese government to join a concerted effort to monopolize this precious public health resource (Cooper, 2020). In another event, Sinophobia even targeted a Canadian government official. Conservative Member of Parliament Derek Sloan criticized the work of Theresa Tam, Canada's chief public health officer working under the Liberal's leadership, questioning whether she was "working for Canada or working for China", while claiming that "Chinese Communist propaganda must never again have a say over Canada's public health" (Boutilier, 2020). This accusation makes implicit reference to the fact that Theresa Tam is ethnic Chinese born in Hong Kong, even though 
under her leadership, Canada's response to Covid-19 has been internationally seen in a positive light (Béland et al., 2021). In both examples, we witness how suspicion of China is nimbly transferred to suspicion of immigrants of Chinese backgrounds.

Perpetuated by politicians and media, anti-China sentiments inevitably spill over to the general public and invoke discrimination against Chinese immigrants. In the U.S., one Sinophobic comment claimed that China is horribly overpopulated so that there should be a zero-child policy, and that Chinese are filthy, plague-spreading people who deserve to die (Borja et al., 2020b, 4). Here, the discourse weaves together China's overpopulation, child policy, and Covid-19 to imagine a scenario in which Chinese justifiably die out. A student leader in a Canadian university, with references to China's Muslim internment camps, commented publicly that "the Chinese people deserve the virus as a result of their actions" and that "coronavirus is an example of righteous karma". Here, we see a deft slippage from the Chinese government's behavior to the culpability of the population as a whole.

In addition, Covid-related Sinophobic discourses frequently reflected a growing perception of China threat. For example, a popular conspiracy theory that China bioengineered coronavirus implicitly positions China's manufacturing technology to be a threat to world order. Meanwhile, some people opt to challenge the China threat discourse. An Instagram joke that "coronavirus won't last for long because it is made in China" makes a derogatory association between coronavirus and China's manufacturing capacity, and in so doing, relieves the Western apprehension (Beech, 2020). In both cases, commentators take advantage of Covid as a discursive opportunity to negotiate the veracity of China threat. Regardless of their different assessments, there is a shared underlying political anxiety leading to unfavorable framings of China.

Sinophobic discourses also reflect the on-going US-China trade war. In the U.S., one hate voice mail message sent to a Chinese claimed:

I just wanted to let you know that China has lost their best customer, America. Everybody in America is not going to buy Chinese anymore, so I hope that your country struggles and everybody has no money. I think it's pretty ignorant for your government not to protect that virus; to let that virus come out and ruin the world. Thanks, China (Borja et al., 2020b, 3).

In the above, I have examined Sinophobic discourses that seek to establish relations between Covid-19 and Chinese politics, and in so doing, contribute to the triple conflation. Readers might find many of the political claims to be contrived and lacking persuasive power. For example, it is far-fetched to draw a connection between China's overpopulation and the emergence of Covid-19; the comment on the Muslims' situation in China has to resort to mystical divine power to make its point; the "communist coronavirus" moniker is a highly inaccurate description of contemporary China's political economy. From an analytic point of view, these are poor discursive constructions. Yet, the lack of analytic rigor precisely makes these discourses interesting: the conspicuous signs of human efforts in making up these claims reveal a strong impulse against China. These discourses in the making are indicative of deepseated political discontent awaiting an opportunity for expression, which turned out to be the Covid crisis. 
That said, the poor quality of these political discourses does pose one question. One might wonder how such contrived discourses have been able to propagate and incite Sinophobic sentiments. In order to answer this question, in the next section, I turn to a different psychological mechanism: metaphor. Unlike discourse which prioritizes the representation of external events, metaphor taps into the imaginative, affective and subjective processes of the mind.

\section{Bio-Political Metaphors}

In this section, I turn to illness as metaphor to explain how mental representations of coronavirus, the Chinese race, and the Chinese politics are cemented together imaginarily and affectively. My analysis is a critical continuation of Sontag's (2001) influential essay "Illness as Metaphor", where she discusses how various imaginaries and fantasies were attached to tuberculosis and cancer. Inspired by Sontag, scholars have discussed the use of military metaphors to describe campaigns against cancer, such as "war on cancer" (Penson et al., 2004, 708), as well as the killer metaphor to highlight SARS's threat (Wallis \& Nerlich, 2005). Today, both metaphors have been repurposed to depict Covid-19 (Chapman \& Miller, 2020). In these examples, illness constitutes the target domain, namely an abstract topic to be explained with the help of a source domain which is more concrete (such as war and killer).

In my study, however, I am interested in a reverse metaphoric formation. I argue that our increased familiarity with Covid-19 has rendered it capable of serving as a source to explain - or in Serge Moscovici's (2000) word, anchor - less tangible topics, such as politics. This metaphoric formation is illustrated by the Wall Street Journal article titled "communist coronavirus" (Henninger, 2020). The author of the article suggested that face masks and mass lockdowns of Chinese cities are metaphors of the Chinese Communist Party's attempt to control what people can say and do. Further, he suggested that he saw coronavirus to be a metaphor reminding us of the interconnectivity and hyper mobility of today's world, a reality captured by the internet phrase "going viral", another disease-related metaphor.

What makes Covid a good material for metaphor? According to Sontag (2001), "illnesses have always been used as metaphors to enliven charges that a society was corrupt or unjust" (p. 72). Covid-19 is particularly convenient for such a purpose because of the grave challenges it poses to the world. The fear, worry, and loss caused by Covid-19 could be easily translated to antipathy toward China and Chinese. Sontag (2001) also mentions that "Any important disease whose causality is murky, and for which treatment is ineffectual, tends to be awash in significance... Feelings about evil are projected onto the disease. And the disease (so enriched with meanings) is projected onto the world" (p. 58). Covid-19, again, fits this profile because it is highly incalcitrant. When Covid metaphors are used to comment on political issues, they become a type of bio-political metaphor which possesses much potential to generate a heightened sense of political urgency by invoking felt illness experience. By capturing embodied sense of threat, Covid metaphors have much capacity of channelling political animosity to racial hatred. 
It seems that Sontag has given a straightforward answer to the use of Covid metaphors. According to her, because metaphoric ways of thinking can easily stigmatize illness, a biomedical view of illness should be a better alternative. In this regard, I join a few scholars in rejecting Sontag's proposal (Brandt, 1988; Kearns, 1997; ScheperHughes \& Lock, 1986). It is true that biomedical understanding of illness has proved to reduce stigma in some areas. But, scientific thinking does not always curb racism. The history of scientific racism demonstrates that even science could serve as a new site of racism (Farber, 2011). In February 2020, Broadcaster Bill Mitchell tweeted a question: "I read that Asian lungs have more receptors and are therefore more susceptible to this kind of virus. Is this true or urban myth?" (O'Sullivan, 2021) Here, Mitchel presents a hypothesis that is both biomedical and racist.

Now, let us return to metaphoric view of illness. Key metaphor scholars have suggested that it is impossible to eliminate metaphoric thinking, not even in a modern time dominated by scientific worldview (Lakoff \& Johnson, 2008). Let me illustrate this point with a racist incident in a Brooklyn subway train in March 2020. There, a non-Asian male rider repeatedly demanded an Asian young man to move away, and, after failing to produce the desired response, he sprayed a can of Febreze air freshener at the Asian man from head to toe for 15 seconds (Parascandola \& Tracy, 2020). This act was highly intriguing. Usually, when a verbal demand fails to elicit a response, physical violence could be the next resort to add further pressure. Febreze spray, however, does not pose any real physical threat. Then, what was the point of doing this?

I argue that Febreze spray is symbolically significant. The fact that Covid-19 is a respiratory disease that spreads through air-borne virus requires individuals to protect themselves primarily through respiration-related hygienic measures, such as the use of face masks. Thanks to Louis Pasteur's germ theory of disease, nowadays people with basic scientific literacy can easily imagine coronaviruses floating in the air during the course of transmission. Such scientific imagiry is visualized in several popular experimental demonstrations that blow powder in the air to represent the patterns in which coronavirus spreads. Given such popularized scientific thinking, the vaporized Febreze chemical particles could be imagined to form a protective wall in the air to fend off potentially spreading coronavirus. The odor-eliminating capacity of Febreze further symbolizes a purifying power to repeal the infectious virus.

It is true, as readers would caution, that we cannot as certain that the racist indeed had such an imagination in his mind, whether consciously or unconsciously. But, there is no denying the symbolic insult: forceful application of air freshener on a human being is a deep affront. Further, the Febreze spray was not an isolated incident. In Florida, a man was video recorded to chase an Asian lady with a bottle of Purell sanitizer while shouting racist slurs (Samson, 2020). In both scenarios, Asian individuals were targeted by strangers to be objects requiring cleansing and disinfection. In these performances, unlike expected by Sontag, biomedical view of illness does not eliminate metaphoric thinking. Instead, biomedical worldview generates new forms of racist metaphor.

Given the assimilating power of metaphoric thinking, it is more productive to use metaphor as an analytic tool to explore how Covid is inscribed with meanings in 
our historical and cultural contexts (Brandt, 1988; Kearns, 1997; Scheper-Hughes \& Lock, 1986). Further, illness metaphor does more than representing the milieu it is embedded in; it instead plays an important role in the construction of social reality by predisposing people to certain imaginaries while downplaying others (Lakoff \& Johnson, 2008). In the following, I analyze how particular illness-based metaphoric imageries are attached to China/Chinese, leading to the triple conflation. Meanwhile, consistent with this study's overarching interest in geopolitics, I also discuss how spatial thinking underlies these metaphors.

I argue that spatial thinking hinges on an implicit metaphor of "contagion" (Mitchell, 2012). While contagion can sometimes be associated with positive states, e.g., happiness, it may easily slide into a negative notion of "contamination", such as in the case of illness (Davis, 2002). Back in the late nineteenth century, a commissioner reported that Vancouver's Chinatown was an "ulcer" that was "lodged like a piece of wood in the tissues of the human body, which unless treated must cause disease in the places around it and ultimately the whole body" (Anderson, 1991, 81). This vividly narrated illness metaphor invokes the audience's primal horror of disease and death. The choice of ulcer-which manifests in clusters and has the potential to progressively erode nearby areas of the body - as a metaphor effectively calls for urgent damage control. The spatial thinking underlying the ulcer metaphor parallels my previous discussion of containment measures targeting Chinese as a source of public health risk.

Now, let us zoom in on Covid metaphors. In February 2020, a Wall Street Journal article claimed that coronavirus has revealed China to be the "real sick man of Asia" (Mead, 2020). This metaphoric label reflects bodies politic, to borrow Andreas Musolff's (2003) concept. According to Musolff (2003), languages of health and illness are powerful metaphors to depict the wellbeing of a society, such as the use of "Euro-sclerosis" to portray the immobility of economic and political affairs of the European Union (p. 332). Although the sick man moniker has been applied to several nations, including the Ottoman Empire, Britain and Italy, the use of it for China today is particularly telling. Starting with a critical discussion of China's initial failed response to the virus outbreak, the Wall Street Journal article invited its readers to be wary of further economic consequences of China's epidemic (combined with several other existing financial problems) and its possible impact on the global market (Mead, 2020). By positioning the "sick man" in the Asian continent, this geographically oriented metaphor functions seamlessly with the author's prediction of international diversification of supply chains away from China. With a grave warning that China's "financial market may be even more dangerous than its wildlife market", the author took Covid-19 as an omen that foreshadowed a possible financial crisis around the globe (Mead, 2020). By highlighting the spatial dimension of the Covid metaphor, the author adeptly taps into the geopolitics of global finance.

As implied in the "sick man of Asia" metaphor, spatial thinking is not always free from value judgements. It can easily fuel geopolitical struggles. Take the "communist coronavirus" expression for example (Henninger, 2020). I argue that "communist coronavirus" is an exemplary bio-political metaphor that fuses viral and political contaminations into one, highlighting the potential of both to spread and lead 
to arguably disastrous ends. When the heightened sense of vigilance against China extends to Chinese people, the latter comes to be seen as suspicious bio-political aliens capable of transmitting coronavirus as well as communist values. For example, amid numerous accusations of Chinese immigrants for spreading coronavirus, a grocery shopper referred to a fellow patron of Chinese background as "another one of those damn Chinese trying to infect everyone into communism" (Borja et al., 2020b, 3).

The bio-political metaphor "communist coronavirus" as well as the underlying spatial thinking of "contagion" call for the policing of national boundaries against penetration. The discipline of boundary against viral/political contagion can be elucidated by a reverse reading of Martin's (1990) anthropology of immunology. According to Martin (1990), the human immune system is popularly conceptualized to function like an army defending the nation from external invasion. Covid-19 metaphors, I argue, appear to reverse the relationship between health and nation in Martin's analysis by positing that when a nation face threat from an alien virus, it must enhance the border control in defense of the health of its citizenry. U.S. politicians' insistence on the use of the "China virus" and "foreign virus" expressions reinforces a protectionist impulse to keep coronavirus at bay, just like the immune system's defense against the intruding foreign cell as "a guy who doesn't speak our language" (Martin, 1990, 414).

Martin (1990) identifies one vivid metaphor introduced by a popular textbook in the U.S.: "it can be as difficult for our immune system to detect foreignness as it would be for a Caucasian to pick out a particular Chinese interloper at a crowded ceremony in Peking's main square" (Dwyer, 1988, 29). It is not necessarily a pure coincidence that the textbook positioned Chinese as the fugitive Other and the Caucasian as the guard: the textbook introduced this metaphor in 1988 during the Cold War. The textbook continued to assert that in spite of the difficulty, the detective efforts are worthwhile because "anything foreign that should dare to invade that environment must be rapidly detected and removed" (Dwyer, 1988, 29). At a time of Covid crisis, the renewed discourse of communism re-activates the long-standing history of Cold War hostility against China and Chinese.

In this section, I have borrowed major metaphor theorists including Sontag (2001), Lakoff and Johnson (2008), Musolff (2003) and Martin (1990) to analyze the power of illness metaphor in symbolically and imaginatively weaving health, racial and national/political issues together. As demonstrated in the example of Febreze spray, metaphor is a fundamental way through which we perceive reality and cannot be simply replaced by rational, scientific worldviews. Covid metaphors, such as "sick man of Asia" and "communist coronavirus", frequently draw on an implicit spatial thinking of "contagion". The geopolitical struggles between China and the West not only mirrors the Cold War, but also re-activates its ideological legacy, as evidenced by the resurgence of discourse about communism by journalists and lay persons alike. Martin's (1990) analysis of immunology in particular sheds light on the parallelism between physical health and national territory in that both require the discipline of boundary, against which Chinese are metaphorically imagined to be bio-political aliens worthy of surveillance. 


\section{Conclusion}

In this article, I analyzed the formation of Sinophobia in the wake of the Covid19 pandemic. The current Sinophobia has been popularly understood to involve a stereotypical association of Chinese and coronavirus. In this study, however, I argued that Chinese are sometimes also discriminated against because of their perceived national/political links to China, which has recently encountered risen antipathy from the West. Taking the political dimension into account, I argued that there has been a "triple conflation" of the health, racial and national/political statuses of Chinese in today's Sinophobia.

In order to understand the phenomenon of triple conflation, I examined Sinophobic actions initiated by governments, politicians, media, businesses and lay persons in North America, Australia, New Zealand, and Western Europe. My research design was ethnographically informed in that it favoured contextualized, interpretive approaches over positivist approaches. Accordingly, rather than using proceduralized methods of data collection, I opted for purposeful sampling that revealed a holistic account of the social, psychological and symbolic processes contributing to Sinophobia.

My study applied three interdisciplinary approaches to yield three respective major findings. First, I applied sociological analysis to examine the politics of spatial belonging. I argued that the Covid crisis has led to widespread use of containment measures such as travel restriction, barring from business premises, and interpersonal physical distance, frequently targeting Chinese as suspected sources of health risk. The spatial dimension of containment explains why current Sinophobia often involves the denial of Chinese rights to certain social and physical spaces. When border control, business owners and lay persons exclude Chinese for suspected health risks, they choose the targets by confusedly using both Chinese racial and national statuses as identity markers. This is one of the mechanisms that give rise to the triple conflation.

Second, I applied a discursive approach to examine how politicians, media and lay persons alike incorporated anti-China political claims into discussions of the Covid pandemic. I argue that problematic naming of coronavirus (such as "China virus" and even "communist coronavirus") tapped into the global rise of xenophobia but also involved controversies regarding the origin of coronavirus. Further, anti-China sentiments frequently translated into suspicion of the political loyalty of Chinese immigrants, not only those who purchased and mailed face masks to China but also high-level government officials. In addition, political commentators took advantage of the Covid crisis as a springboard to probe a wide range of Chinese political issues including population policy, human rights condition, manufacturing technology and international trades. All these discourses melt health, racial and national/political issues in one pot.

Third, I adopted an interpretive approach to analyze how Covid metaphors attach particular symbols and imageries to China/Chinese to achieve a triple conflation. Covid metaphors matter because they are capable of activating our embodied sense of threat and thereby animate racial/political hostility. Drawing 
on major metaphor theorists including Sontag (2001), Lakoff and Johnson (2008), Musolff (2003) and Martin (1990), I analyzed the embodied metaphor of Febreze spay, the illness metaphor of ulcer and the underlying idea of "contagion", the geopolitical metaphor of "sick man of Asia", the bio-political metaphor of "communist coronavirus", as well as the idea of boundary in popular conception of immunology and national territory in parallel. These mental representations of spatial separation mirror the containment behaviors I analyzed earlier. To sum up, my three sections - the spatial politics of containment, the construction of political discourse, and bio-political metaphors - are unified under the geopolitics of belonging, in which Chinese people's rights to certain social and physical spaces are contested.

Funding This research project was funded by the Social Sciences and Humanities Research Council of Canada, 756-2019-0092.

Data Availability Data available upon request.

\section{Declarations}

Ethics Approval The research project was reviewed and approved by the ethic offices of Simon Fraser University and York University.

Consent for Publication I consent this contribution to be published by Integrative Psychological and Behavioral Science.

Conflicts of Interest/Competing Interests There are not conflicts of interest.

\section{References}

Anderson, K. J. (1991). Vancouver's Chinatown: Racial discourse in Canada, 1875-1980. McGillQueen's Press-MQUP.

Antonsich, M. (2010). Searching for belonging-an analytical framework. Geography Compass, 4(6), 644-659.

BBC News. (2021). Coronavirus: Boy sentenced for racist street attack. BBC News, January 27, 2021, sec. London. https://www.bbc.com/news/uk-england-london-54048546.

Beech, H. (2020). Quieter response to coronavirus in countries where China Holds Sway. The New York Times, February 2, 2020, sec. World. https://www.nytimes.com/2020/02/02/world/asia/china-coron avirus-philippines-thailand.html.

Béland, D., Dinan, S., Rocco, P., \& Waddan, A. (2021). Social policy responses to COVID-19 in Canada and the United States: Explaining policy variations between two Liberal welfare state regimes. Social Policy \& Administration, 55(2), 280-294.

Bischoping, K., \& Gazso, A. (2016). Analyzing talk in the social sciences: Narrative, conversation and discourse strategies. Sage.

Boddy, C.R. (2016). Sample size for qualitative research. Qualitative Market Research: An International Journal, 19(4),426-432.

Bogerd, E. (2020). Online Nationalism in China: Weibo reactions to the detention of Huawei CFO Meng Wanzhou. Master's thesis, Leiden University, Netherlands.

Borja, M., Gibson, J., Gowing, S., Lee, T., Lui, J., Zhou, W., \& Jeung, R. (2020a). The Return of 'Yellow Peril': Anti-AAPI Rhetoric and Policies Leading up to the 2020 Election. Stop AAPI Hate. https:// 
stopaapihate.org/wp-content/uploads/2021/04/Stop-AAPI-Hate-Report-2020-Candidates-and-AntiAsian-Rhetoric-201021.pdf. Accessed 8 Mar 2021.

Borja, M., Jeung, R., Yellow Horse, A.J., Gibson, J., Gowing, S., Lin, N., Navins, A., \& Power, E. (2020b). Anti-Chinese Rhetoric tied to racism against Asian Americans. Stop AAPI Hate Report.

Boutilier, A. (2020). 'Does she work for Canada or for China?' Conservative MP's attack on Dr. Theresa Tam draws fire I The Star. Toronto Star, April 23, 2020. https://www.thestar.com/politics/feder al/2020/04/23/does-she-work-for-canada-or-for-china-conservative-mps-attack-on-dr-theresa-tamdraws-no-comment-from-andrew-scheer.html.

Brandt, A.M. (1988). AIDS and metaphor: Toward the social meaning of epidemic disease. Social Research, 55(3), 413-432.

Campbell, S., Greenwood, M., Prior, S., Shearer, T., Walkem, K., Young, S., Bywaters, D., \& Walker, K. (2020). Purposive sampling: Complex or simple? Research case examples. Journal of Research in Nursing, 25(8), 652-661.

Chapman, C. M., \& Miller, D. M. S. (2020). From metaphor to militarized response: The social implications of 'we are at war with COVID-19'-crisis, disasters, and pandemics yet to come. International Journal of Sociology and Social Policy.

Choi, D. (2020). Fox News' Jesse Watters makes remarks about Chinese, demands apology. Business Insider, March 2, 2020. https://www.businessinsider.com/fox-news-jesse-watters-chinese-demandsapology-racism-2020-3.

Christy, A. (2020). Uh Oh! CNN reporter refers to coronavirus as 'Wuhan Virus.' MRC News Busters, March 13, 2020. https://www.newsbusters.org/blogs/nb/alex-christy/2020/03/13/cnn-reporter-referscoronavirus-wuhan-virus.

Cooper, S. (2020). United Front Groups in Canada Helped Beijing Stockpile Coronavirus Safety Supplies. Global News, April 30, 2020. https://globalnews.ca/news/6858818/coronavirus-china-unitedfront-canada-protective-equipment-shortage/.

Corley, J. (2020). Boston Doctor Becomes Victim Of COVID-19 Racism. Here Is How We Should Respond. Forbes, April 14, 2020, sec. Health. https://www.forbes.com/sites/jacquelyncorley/2020/ 04/14/boston-doctor-becomes-victim-of-covid-19-racism-here-is-how-we-should-respond/.

Davis, C. J. (2002). Contagion as metaphor. American Literary History, 14(4), 828-836.

Denzin, N. K. (1997). Interpretive ethnography: Ethnographic practices for the 21 st century. SAGE.

Dionne, K. Y., \& Turkmen, F. F. (2020). The politics of pandemic othering: Putting COVID-19 in global and historical context. International Organization, 74(S1), E213-E230.

Dwyer, John M. 1988. The body at war: The miracle of the immune system. Signet.

Fairclough, N., \& Wodak, R. (1997). Critical discourse analysis. Discourse Studies: A Multidisciplinary Introduction, 2 (357-378).

Farber, P. L. (2011). Mixing races: From scientific racism to modern evolutionary ideas. JHU Press.

Fottrell, Q. (2020). 'No Chinese allowed': Racism and fear are now spreading along with the coronavirus. MarketWatch, February 3, 2020, sec. Personal Finance. https://www.marketwatch.com/story/ no-chinese-allowed-racism-and-fear-are-now-spreading-along-with-the-coronavirus-2020-01-29.

Gao, Z. (2021a). Political identities of Chinese international students: Patterns and change in transnational space. In E. Tartakovsky (Ed.) special issue "Innovations and new discoveries in international migration psychology”, International Journal of Psychology. Page numbers to be assigned.

Gao, Z. (2021b). Unsettled belongings: Chinese immigrants' mental health vulnerability as a symptom of international politics in the Covid-19 pandemic. Journal of Humanistic Psychology, 61(2), 198-218.

Gao, Z. (2021c). Unsettled belongings in deglobalization: Chinese immigrants' struggle for political identity by using transnational media in the COVID-19 pandemic. In J. Pollock \& D. Vakoch (Eds.) COVID-19 in International Media: Global Pandemic Perspectives (pp. 44-54). New York: Routledge.

Gostin, L. O., Bayer, R., \& Fairchild, A. L. (2003). Ethical and legal challenges posed by severe acute respiratory syndrome: Implications for the control of severe infectious disease threats. Jama, 290(24), 3229-3237.

Henninger, D. (2020). A Communist Coronavirus. Wall Street Journal, January 29, 2020. https://www. wsj.com/articles/a-communist-coronavirus-11580341911. Acessed 31 Mar 2021.

Jeung, R., Popovic, T., Lim, R., \& Lin, N. (2020). Anti-Chinese Rhetoric Employed by Perpetrators of Anti-Asian Hate. Stop AAPI Hate. https://stopaapihate.org/wp-content/uploads/2021/04/StopAAPI-Hate-Report-Anti-China-201011.pdf. Accessed 15 Dec 2020. 
Jeung, R., Yellow Horse, A.J., Popovic, T., \& Lim, R. (2021). Stop AAPI Hate National Report. Stop AAPI Hate. https://stopaapihate.org/wp-content/uploads/2021/05/Stop-AAPI-Hate-Report-Natio nal-210506.pdf. Accessed 1 Apr 2021.

Kearns, R. A. (1997). Narrative and metaphor in health geographies. Progress in Human Geography, 21(2), 269-277.

Keil, R., \& Ali, H. (2006). Multiculturalism, racism and infectious disease in the Global City: The experience of the 2003 SARS outbreak in Toronto. Topia: Canadian Journal of Cultural Studies, $16,23-49$.

Kiernan, S. (2020). Travel Restrictions on China Due to COVID-19. Thin Global Health. https://www. thinkglobalhealth.org/article/travel-restrictions-china-due-covid-19. Accessed 16 Jun 2020.

Kim, G. S., \& Shah, T. N. (2020). When perceptions are fragile but also enduring: An Asian American reflection on COVID-19. Journal of Humanistic Psychology, 60(5), 604-610.

Kong, J., Ip, J., Huang, C., \& Lin, K. (2021). A year of racist attacks: Anti-Asian racism across Canada one year into the Covid-19 pandemic. Chinese Canadian National Council, Toronto Chapter.

Krause, E. L., \& Bressan, M. (2020). Viral encounters: Xenophobia, solidarity, and place-based lessons from Chinese migrants in Italy. Human Organization, 79(4), 259-270.

Lakoff, G., \& Johnson, M. (2008). Metaphors we live by. University of Chicago press.

Leung, C. (2008). The yellow peril revisited: The impact of SARS on Chinese and southeast Asian communities. Resources for Feminist Research, 33(1/2), 135.

Li, D.K. (2020). Coronavirus Hate Attack: Woman in Face Mask Allegedly Assaulted by Man Who Calls Her 'Diseased.' NBC News, February 5, 2020. https:/www.nbcnews.com/news/us-news/ coronavirus-hate-attack-woman-face-mask-allegedly-assaulted-man-who-n1130671.

Li, Y., \& Nicholson, H. L., Jr. (2021). When 'model minorities' become 'Yellow peril'-Othering and the racialization of Asian Americans in the COVID-19 pandemic. Sociology Compass, 15(2), e12849.

Manojlovic, D. (2021). Year-End 2020 Year-to-Date Key Performance Indicators Report. Report to the Vancouver Police Board. Vancouver Police Board. https://vancouverpoliceboard.ca/police/ policeboard/agenda/2021/0218/5-1-2102P01-Year-end-2020-KPI-Report.pdf. Accessed 1 May 2021.

Marcus, G.E. (1995). Ethnography in/of the world system: The emergence of multi-sited ethnography. Annual Review of Anthropology, 95-117.

Martin, E. (1990). Toward an anthropology of immunology: The body as nation state. Medical Anthropology Quarterly, 4(4), 410-426.

Martin, R. (2006). The exercise of public health powers in cases of infectious disease: Human rights implications. Medical Law Review, 14(1), 132-143.

Mead, W.R. (2020). China is the real sick man of Asia. Wall Street Journal, February 3, 2020. https:// www.wsj.com/articles/china-is-the-real-sick-man-of-asia-11580773677.

Mitchell, P. (2012). Contagious metaphor. A\&C Black.

Molina, K., Kupfer, M., (2020). 4:48 PM ET I Last Updated: February 15, and 2020. 2020. Ottawa woman with Chinese passport banned from florida cruise over coronavirus fears. $C B C$, February 14, 2020. https://www.cbc.ca/news/canada/ottawa/ottawa-woman-chinese-passport-bannednorwegian-cruise-line-1.5464097.

Moscovici, S. (2000) Social Representations. Explorations in Social Psychology. Cambridge, UK: Polity Press.

Musolff, A. (2003). Ideological Functions of Metaphor: The Conceptual Metaphors of Health and Illness in Public Discourse. Dirven, R., Frank, R. \& Pütz, M. Cognitive Models in Language and Thought: Ideology, Metaphors and Meanings, 327-52.

Musolff, A. (2010). Political metaphor and bodies politic. In Urszula Okulska \& Piotr Cap (eds.) Perspectives in Politics and Discourse, 23-41. John Benjamins Pub. Company

O'Sullivan, E. (2021). Bill Mitchell Ratioed for Peddling Racist Coronavirus 'Urban Myth.' Daily Dot, January 27, 2021. https://www.dailydot.com/irl/bill-mitchell-racist-coronavirus-conspiracy-theory/.

Oaten, M., Stevenson, R. J., \& Case, T. I. (2011). Disease avoidance as a functional basis for stigmatization. Philosophical Transactions of the Royal Society B: Biological Sciences, 366(1583), 3433-3452.

Parascandola, R., \& Tracy, T. (2020). SEE IT: Unhinged NYC Train Commuter Sprays Asian Man with Deodorizer, Fearing He Has Coronavirus. New York Daily News, March 5, 2020. https://www.nydai 
lynews.com/new-york/nyc-crime/ny-cops-investigating-anti-asian-bias-crime-20200305-7w3olaoujf e4fmb6npccdq2t2i-story.html.

Patey, L. (2021). How China loses: The pushback against Chinese global ambitions. Oxford University Press.

Patton, M.Q. (2007). Sampling, Qualitative (Purposive). In George Ritzer (ed.)The Blackwell Encyclopedia of Sociology. John Wiley \& Sons, Ltd. https://doi.org/10.1002/9781405165518.wbeoss012. pub2.

Penson, R. T., Schapira, L., Daniels, K. J., Chabner, B. A., \& Lynch, T. J. (2004). Cancer as metaphor. The Oncologist, 9(6), 708-716.

Reny, T. T., \& Barreto, M. A. (2020). Xenophobia in the time of pandemic: Othering, anti-Asian attitudes, and COVID-19. Politics, Groups, and Identities. https://doi.org/10.1080/21565503.2020. 1769693.

Samson, C. (2020). 'Sanitize your A**!': Man chases elderly Asian woman with Purell in viral video. NextShark, March 16, 2020. https://nextshark.com/purell-man-chases-elderly-asian/.

Saukko, P. (2003). Doing research in cultural studies: An introduction to classical and new methodological approaches. Sage.

Scheper-Hughes, N., \& Lock, M. M. (1986). Speaking" truth" to illness: Metaphors, reification, and a pedagogy for patients. Medical Anthropology Quarterly, 17(5), 137-140.

Schild, L., Ling, C., Blackburn, J., Stringhini, G., Zhang, Y., \& Zannettou, S. (2020). 'Go Eat a Bat, Chang!': An Early Look on the Emergence of Sinophobic Behavior on Web Communities in the Face of Covid-19. ArXiv Preprint ArXiv:2004.04046.

Snowden, F. M. (2019). Epidemics and society: From the black death to the present. Yale University Press.

Sontag, S. (2001). Illness as metaphor and AIDS and its metaphors. Macmillan.

Stefano, S., \& Noack, R. (2020). A top European music school suspended students from East Asia over coronavirus concerns, amid rising discrimination. Washington Post, January 31, 2020. https://www. washingtonpost.com/world/2020/01/31/top-european-music-school-suspended-students-east-asiaover-coronavirus-concerns-amid-rising-discrimination/.

Tavernise, S., \& Oppel, R.A. (2020). Spit on, yelled at, attacked: Chinese-Americans fear for their safety. The New York Times, March 23, 2020. https:/www.nytimes.com/2020/03/23/us/chinese-coronavirus-racist-attacks.html.

Teo, T. (2017). From psychological science to the psychological humanities: Building a general theory of subjectivity. Review of General Psychology, 21(4), 281.

Trumper, R., \& Phillips, L. (1997). Give me discipline and give me death: Neoliberalism and health in Chile. International Journal of Health Services, 27(1), 41-55.

Van Dijk, T. A. (2001). Critical discourse analysis. In D. Schiffrin, D. Tannen, \& H. E. Hamilton (Eds.), The handbook of discourse analysis (pp. 352-371). Blackwell Publishers.

Viladrich, A. (2021). Sinophobic stigma going viral: Addressing the social impact of COVID-19 in a globalized world. American Journal of Public Health, 111(5), 876-880.

Wallis, P., \& Nerlich, B. (2005). Disease metaphors in new epidemics: The UK media framing of the 2003 SARS epidemic. Social Science \& Medicine, 60(11), 2629-2639.

Wang, S., Chen, X., Li, Y., Luu, C., Yan, R., \& Madrisotti, F. (2021). 'I'm more afraid of racism than of the virus!': Racism awareness and resistance among Chinese migrants and their descendants in France during the Covid-19 pandemic. European Societies, 23(sup1), S721-S742.

White, A. I. R. (2020). Historical linkages: Epidemic threat, economic risk, and xenophobia. The Lancet, 395(10232), 1250-1251. https://doi.org/10.1016/S0140-6736(20)30737-6

Wilder-Smith, A., \& Freedman, D. O. (2020). Isolation, quarantine, social distancing and community containment: Pivotal role for old-style public health measures in the novel coronavirus (2019NCoV) outbreak. Journal of Travel Medicine, 27(2), taaa020.

Willig, C. (2017). Interpretation in qualitative research. In Carla Willig \& Wendy Stainton Rogers (eds.),The SAGE Handbook of Qualitative Research in Psychology, 274-288.

Xu, J., Sun, G., Cao, W., Fan, W., Pan, Z., Yao, Z., \& Li, H. (2021). Stigma, discrimination, and hate crimes in Chinese-speaking world amid Covid-19 pandemic. Asian Journal of Criminology, 16(1), 51-74.

Yeung, L. (2020). Early efforts by B.C.'s Chinese community to curb COVID-19 should be 'applauded,' Doctor Says I CBC News. CBC, June 8, 2020. https://www.cbc.ca/news/canada/british-columbia/ early-efforts-by-chinese-community-to-curb-covid-19-should-be-applauded-says-b-c-doctor- 1 . 5600943. 
Yuval-Davis, N. (2006). Belonging and the politics of belonging. Patterns of Prejudice, 40(3), 197-214.

Zhao, S. (2021). Rhetoric and reality of China's global leadership in the context of COVID-19: Implications for the US-led world order and Liberal globalization. Journal of Contemporary China, 30(128), 233-248.

Publisher's Note Springer Nature remains neutral with regard to jurisdictional claims in published maps and institutional affiliations.

Zhipeng Gao is Assistant Professor in the Department of Psychology, Health and Gender at the American University of Paris. He received PhD training in Historical, Theoretical and Critical Studies of Psychology at York University, and conducted postdoctoral research in Sociology and Anthropology at Simon Fraser University. His current research focuses on Chinese immigrants' identity, belonging, and mental health against cultural and political contexts. Meanwhile, he has been studying the history of psychology and psychotherapy in China's communist movement. He has published 20 refereed essays in journals and edited volumes including Journal of Humanistic Psychology, Review of General Psychology, International Journal of Psychology, History of Psychology, Social Anthropology, and Narrative Inquiry. He is currently guest (co)editing two special issues on Chinese psychology and the psychology of deglobalization for Integrative Psychological and Behavioral Science (Springer) and Theory \& Psychology (Sage). 